\title{
EFFECT OF TECHNOLOGICAL CHANGES ON AIRPORT SECURITY PERSONNEL: AGE-RELATED ANALYSIS
}

\author{
DOI: 10.17261/Pressacademia.2019.1157 \\ RJBM- V.6-ISS.4-2019(4)-p.271-280
}

\section{Savas S. Ates}

Eskisehir Technical University, Faculty of Aeronautics and Astronautics, Aviation Management, Eskisehir, ssates@eskisehir.edu.tr, ORCID: 0000-0003-2462-0039

Date Received: June 28, 2019

Date Accepted: December 8, 2019

To cite this document

Ates, S. S., (2019). Effect of technological changes on airport security personnel: age-related analysis. Research Journal of Business and

Management (RJBM), V.6(4), p.271-280.

Permemant link to this document: $\underline{\text { http://doi.org/10.17261/Pressacademia.2019.1157 }}$

Copyright: Published by PressAcademia and limited licenced re-use rights only.

\begin{abstract}
Purpose- The aim of the study is to determine the impact of technological changes on age-based airport security personnel. Due to its strategic importance, airports have the potential to attract danger. There have been terrorist attacks at airports since the early years of aviation. Security control processes have been developed and implemented at airports since the 1970s. The airport security processes vary depending on the threat profiles. With the September 11, 2001 twin tower attacks, the world's aviation security processes have completely changed. Over the last decade, changes in the threat profile have occurred. The main purpose of aviation is to provide service to passengers by creating space and time benefits. The balance of passengers' comfort and safety to be maintained by air depends on the type of threats and the technology used in security. For this reason, large investments are made in the development of security technology at airports.

Methodology- 28-item questionnaire was applied to the airport security officers over the internet. 276 security personnel working in airports participated in the study. Age-based analysis was performed using chi-square analysis. In this process, small-scale, relatively simple security systems at the airports, large-scale, high-tech systems were introduced. New technological systems are digital, networked, software oriented and mobile solutions. Although there is a rapid change in airport security technologies, the security personnel and the human element using the technology remain the same. Considering that human factor is the user of technology, the attitude of individuals towards technology is effective in ensuring airport security. Technological change has had a significant impact on the attitudes, behaviors and mental structure of the employees. Technological change causes many psychological effects such as monotony, boredom, fatigue, stress and anxiety.

Findings- In the survey conducted to evaluate the approach of airport security personnel to technological change, $67 \%$ of security personnel were exposed to technological changes. The respondents defined technology as convenience and convenience (37\%), innovation (36.6\%) and efficiency (15.2\%). Airport security personnel preferred to provide training and courses on the technology to be applied (48.6\%) for the adoption of the new technology and $51.4 \%$ stated that they adopted the latest technological development applied in airport security in 7 days and under 6 days. 59.8\% of the respondents stated that the technological change in airport security brought about an increase in the level of security.

Conclusion- As a result of findings, it can be said that the management of technological change is important for organizations. Ensuring security at airports is important in terms of minimizing the psychological, social, economic and physical impacts of technology on security personnel due to the key human factor. Training of security personnel before the technological change to be applied increases the interaction between technology and individual and contributes to the personnel to make appropriate decisions because it recognizes the technology.
\end{abstract}

Keywords: Security technologies, airport security, technological change, age-based analysis. JEL Codes: L91, L93, L98

\section{INTRODUCTION}

Developing technology enables individuals to increase their knowledge levels, facilitate information sharing and the way of doing business. Moreover, it is necessary to understand, recognize and learn new technologies that significantly affect business life. The benefits of technological developments in business life depends on the human factor who use technology (Cascio \& Montealegre, 2016).

The parallel of the increasing popularity of air transport increases the use of airports. Airports, strategically important for the country, have been the focus of terrorist actions since the first age of the aviation. Therefore, procedures are taken to increase 
the security level in airports. In particular, security must be ensured at the entrance to the terminal building, which is the starting point for an illegal action against airports. Security scans for passengers, baggage or personnel at airports are increasingly being carried out with high-tech devices that make it easier to identify potential hazards and threats. However, the assessment of the security level with only technological devices can be wrong in airports. Because the security personnel of the airports, which are technology users, are the decision makers and the assurance person for providing security level (Alards-Tomalin, ve diğerleri, 2014).

Airport authority have to consideration to adaptation problem and effect of the technological changes on the airport security officers. Moreover, it is important to avoid security gaps because of adaptation problem of technological changes.

In the first part of this research; the technological advances in airport security and the impact of technology on the employee. Civil aviation security services, legal regulations, and passenger terminal building security issues are discussed in the second part. At the last section, the findings of the survey "Impact of Technological Changes on Airports Security Personnel" questionnaire applied to 276 people consisting of DHMi and private airport security company security officers were evaluated and explained. SPSS 15.0 program was used for these evaluations and Chi-Square analyzes were performed on the data.

\section{LITERATURE REVIEW}

The word technology comes from two Greek words, transliterated techne and logos. Techne means art, skill, craft, or the way, manner, or means by which a thing is gained. Logos means word, the utterance by which inward thought is expressed, a saying, or an expression. So, literally, technology means words or discourse about the way things are gained (Oregon State University, 2018).

\subsection{Technological Change}

Technology is defined as information on the maintenance of daily operations. Technological change can be defined as the increase of this information. It is seen that the products whose technological change mostly occurs in the form of new production methods, new designs that change the important qualities of production, marketing and management techniques (Aydın, 2013).

Technological change not only changes the production process and the nature of the goods produced, but also changes the human in the process starting from its labor. Technological change means the application of new knowledge and skills. This means the change of labor in the production process. The new technology raises the need for well-trained, skilled labor (Dertli, 2008).

\subsection{Technological Changes and Developments in Airport Security}

All the airports providing air transportation services are included in the international system. Due to the unique sensitivity of airports, large airports with heavy passenger volumes require detailed equipment systems and advanced technology security measures and the importance of personnel selection (Ashford, Stanton, \& Moore, 1996). Security scanning technologies are used to check passengers or their baggage (Singh \& \& Singh, 2013).

Airport security history shows significant changes in security control processes since the early 70s of the last century. During this time, threat profiles have changed dramatically. Since 2001, suicide bombing has become a real risk for civil aviation. In the last 15 years, these changes in the threat profile have made major investments in the development of new security technology, along with efforts to facilitate the transport of passengers by air (Hofer \& Wetter, 2012).

It is possible to list some of the important security services at the airports as follows (Kardeş, Yılmaz, Ateş, Sayın, \& Gemici, 2014):

- $\quad$ Passenger and baggage screening at terminal entrance control points,

- Screening of passenger and cabin baggage at the check-in points at the purified site,

- Ensuring security of entrance and exit of terminal parking lot,

- Ensuring the security of terminal entrance and exit doors,

- Scanning baggage in the baggage separation area,

- Ensuring the security of the aircraft waiting in the apron parked against external attacks,

- $\quad$ Taking permissible weapons from the aircraft to the weapon delivery point and from the weapon delivery point to the aircraft,

- Transportation of money or valuables from the aircraft to the designated delivery point at the airport or from the delivery point to the aircraft, 
- Additional safety screening and checks during the process of loading passengers and cabin baggage to the aircraft,

- Profiling and checking of travel documents while boarding passengers,

- Aircraft search and control service,

- Ensuring the safety of cargo buildings and control of cargo to be loaded onto the aircraft.

In this context, some of the technologies used in airport security worldwide are as follows:

- $\quad$ Reflective $x$-ray imaging systems: This makes it a suitable technology for detecting both liquid and solid explosives as well as for the detection of drugs (Elias, 2009, s. 217).

- 3D Millimetric Wave Scanners: An imaging system that can penetrate clothing to display items hidden by clothing. These techniques have been produced from microwave holography techniques (Sheen, McMakin, \& Hall, 2001). This technology displays an extremely different image that makes it easier to recognize the potentially dangerous object. Microwave hologram imaging, unlike a security scanner has the potential to create clear images for substances that can be overlooked (Sweet, 2009, s. 295).

- Biometric security systems: Biometric security systems recognize individual physical characteristics such as fingerprints, signatures, voice, retina. Another popular biometric access control system uses the technique of recognizing threedimensional data about a person's hand geometry. Biometric systems are two types: identification and verification. The biometric identification device automatically verifies the identity of a person by measuring a physical property or reproducible action of the person. Verification systems, on the other hand, require the use of identities such as cards that contain some physical characteristics of that person to perform verification procedures (Sweet, 2009, s. 299)(Sweet, 2009.

\subsection{Effects of Technological Changes on Employees}

Personnel providing security at airports are individuals who contribute to the detection of a potential threat (face, baggage or person) with the technologies it uses. Security personnel are expected to make appropriate action plans by increasing the threat level, if necessary. Therefore, security personnel may be asked to operate, monitor, and even undertake other tasks not related to the operation of the technology (Jain \& Kumar, 2011, s. 150). Since technological changes will have different effects on each individual, it is important to examine this issue.

\subsection{Psychological Effects of Technological Change on Employees}

It can be said that technological change has a significant effect on the attitudes, behaviors and psychological structure of the employees. It can be said that technological change has emerged as psychological effects on workers, monotony and boredom, fatigue, stress and anxiety (Dertli, 2008).

\subsubsection{Monotony and Boredom}

Monotony is the condition of tiredness and boredom caused by repetitive work. Constant and demanding jobs are boring and more monotonous. Technological changes create changes in the quality and nature of the work, resulting in monotony in the workplace. Lack of opportunities to move the body, routine noise, mental and physical fatigue, non-compliance with work, not being able to get used to night shifts may reveal monotony (Dertli, 2008).

\subsubsection{Stress and Worry}

Stress; it can be defined as physical and emotional reactions caused by imposing, oppression and uncertainty (Gökgöz, 2013). Work stress can be defined as a mismatch arising from the specific structure of the job and the reaction of the employee to his / her own personality while performing the task (Erdoğan, Ünsar, \& Süt, 2009). New technology, rapid changes in the business environment, the skills of employees quickly outdated. In addition, the need to know new equipment and systems constantly reveals the threat situation in the individual. This situation becomes a potential stress factor if adequate training is not provided (Okutan \& Tengilimoğlu, 2002). Technological innovations and those who do not have enough knowledge and experience to work, is in two-sided fear. First; fear of damaging the machine or equipment; Fear of losing the job because it cannot adapt to the new technology (Dertli, 2008). 


\subsection{Social Effects of Technological Change on Employees}

The social effects of technological change on employees; alienation, inadequacy, education.

\subsubsection{Estrangement}

Alienation is a person's life, a life style contrary to the essence of human life or human life does not fit into the way of life is imposed (Dertli, 2008). Alienation to work; it can be said that the reluctance, indifference, boredom, burnout and the inefficiency and conflict that this situation brings together (Gürsoy, 2014). Human re-division of technology and technology has become increasingly alienated in working life. Therefore, employees' relations with other people have decreased. Not only the degree of automation in technology, but also the technological change in work affects alienation. Because technological changes are often perceived as a factor that will lead to deterioration of the environment, bringing new risks related to safety and health, the occurrence of desires and the disruption of social integrity.

\subsubsection{Inadequacy}

Inadequacy is the situation in which those working in a certain position do not care about the knowledge and skills required by new technologies. Technology creates a number of jobs where the knowledge and dexterity of the employees is not sufficient. The replacement of a new invention, a machine, causes many people to change their positions (Adibifar, 2016). The speed of technological change leads to wear and tear of the workers. In addition to the danger of dismissal, the lack of technical knowledge and skills of the employees may also be a source of unrest. Technological change forces people's potential to change.

\subsubsection{Training}

Increasing the current performance of employees, updating their skills, solving organizational problems, being able to make career planning, keeping up with the changes and even guiding, were the factors that increased the importance of training activities. Training programs are organized to increase and improve the knowledge, skills and abilities of human resources. Technology, automation, changing values, computer, communication, information, environment and organizational changes can be listed as the main factors that increase the importance of education (Örücü \& Yumuşak, 2015). Technological changes in organizations greatly change the qualities expected from the individual. The amendments make it necessary to train the employee. As a result of the change in technology, organizations are forced to adapt their employees to the machine. Education, jobs and opportunities should change the self and skills of the employee should change the basis.

\subsubsection{Decrease in Communication and Social Relations}

Technological change can eliminate staff members' co-workers and non-formal relationships with them. Some of his friends may get out of work, some of them may change their chapters or even be unfair.

\subsubsection{Job Dissatisfaction}

One of the important changes brought about by technological advances in working life is undoubtedly related to job satisfaction (Şahin, Aydın, \& Güler, 2015). Job satisfaction can also be defined as a feeling that an employee experiences when he / she realizes that his / her work and the needs and personal values judgments overlap or allow them to overlap. In enterprises applying advanced technology, job descriptions should also be rearranged. These include; considering that the work is done faster with computers, reducing work hours, keeping wages satisfactory, and acquiring completely new division of labor and business principles can be considered (Can, 2008).

In enterprises applying advanced technology, job descriptions should also be rearranged. These include; considering that work is done faster with computers, reducing work hours, keeping wages satisfactory, and acquiring completely new division of labor and business principles can be considered. 


\subsection{The Economic Effect of Technological Change on the Employees}

Technological change has two economic effects on employees: dismissal and job insecurity. The state of weakness in maintaining the continuity of the threatened work; the difference between the expected level of job security and the level of assurance; feelings of uncertainty as to whether an individual's job will continue; the perception of a potential threat to the continuity of work is the definitions made about job insecurity. Concerns about job insecurity are accepted as the heaviest period of the unemployment process and reveal the situation before losing the job (Çakır, 2007). Because the new technology can lead to specializations of different qualifications and make the works of those who worked until then become in a situation that they cannot manage.

\subsection{Physical Effects of Technological Changes on Employees}

Rapid technological developments; on the one hand it serves the welfare of the human being, on the other hand it brings with it the dangers for human life and the environment. Electromagnetic waves are propagated by many natural and man-made sources and the effect of those working on the work environment is inevitable (Dertli, 2008). As a result of technological advances, the use of electromagnetic waves is increasing day by day, and therefore, employees are exposed to high levels of electromagnetic waves in their workplaces. Although electromagnetic waves emitted by some high technology machines and devices cause problems such as headache and insomnia, it has been found to cause short-term effects (Özkan \& Purutçuoğlu, 2010). Kerschner and Chelsvig found that age was effective in the adoption of technological innovations, negative opinions about technology increased and technology usage decreased with increasing age (Özkan \& Purutçuoğlu, 2010).

\section{DATA AND METHODOLOGY}

The use of technology in the world and Turkey is increasing in all areas. Understanding the effects of technological developments on individuals is an important research topic. In civil aviation, technology is used as a tool to take measures that threaten security. This research was carried out to determine the effects of technological changes on security personnel who are technology users in ensuring security at airports. Because of security personnel at airports in Turkey research workers cannot be applicable to all of them reached the 276 airport security personnel survey is one of the limitations of this research. In order to determine the impact of technological changes on airport security personnel, a 28-question questionnaire was applied to airport security officers over the internet. The results of this survey were analyzed using the Chi-Square method with SPSS 15.0 program.

\section{FINDINGS AND DISCUSSIONS}

\subsection{Demographic Data}

276 security personnel working in airports participated in the study. 274 (99.3\%) of the participants were male and 2 (0.7) were female. The age distribution of security personnel working at airports is shown in Table 1 . Two (0.7\%) of the survey participants were 51 years and over, 124 (44.9\%) were in the $41-50$ age range, 150 (54.3\%) were in the 25-40 age range.

Table 1: Age Distribution Table of Airport Security Personnel

\begin{tabular}{lrrrr}
\hline & Frequency & Percentile & $\begin{array}{r}\text { Current } \\
\text { Percentile }\end{array}$ & $\begin{array}{r}\text { Total } \\
\text { Percentile }\end{array}$ \\
\hline 51 years and older & 2 &, 7 &, 7 &, 7 \\
$41-50$ years old & 124 & 44,9 & 44,9 & 45,7 \\
$25-40$ years old & 150 & 54,3 & 54,3 & 100,0 \\
Total & 276 & 100,0 & 100,0 & \\
\hline
\end{tabular}

The education levels of the security personnel working at the airports are as follows $1(\% 0,4)$ primary school, $36(\% 13)$ high school, 80 (\%29) associate degree, 150 (\%54.3) master's degree, 9 (\%3.3) master's degree (Table 1).

The seniority periods of the security personnel working at the airport are as shown in Table 5.4 (1.4\%) of the survey participants were between $1-5$ years, $13(4.7 \%)$ were between $6-10$ years, $46(16.7 \%)$ were between $11-15$ years, $213(77.2 \%)$ were more than 16 years has seniority periods. 
Table 2: Table of Distribution of Seniority Periods of Airport Security Personnel in the Profession

\begin{tabular}{lrrrr}
\hline & Frequency & Percentile & Current Percentile & Total Percentile \\
\hline $1-5$ years & 4 & 1,4 & 1,4 & 1,4 \\
6-10 years & 13 & 4,7 & 4,7 & 6,2 \\
$11-15$ years & 46 & 16,7 & 16,7 & 22,8 \\
16 years and above & 213 & 77,2 & 77,2 & 100,0 \\
Total & 276 & 100,0 & 100,0 & \\
\hline
\end{tabular}

Table 2 shows the security personnel working at airports that are open to business innovations. The responses of the respondents are as follows $185(\% 67)$ were totally agree, $81(\% 29,3)$ were agree, $5(\% 1,8)$ were undecided, 2 (\%0,7) were disagree, $3(\% 1,1)$ were disagree at all.

\subsection{Technological predisposition}

The distribution of the meaning of technology for security personnel working in airports is shown in Table 3. "What comes to your mind first when you hear about the concept of technology?" The responses of the respondents for the question are as follows $101(\% 36,6)$ were innovation, 102 ( $\% 37)$ were convenience and comfort, $42(\% 15,2)$ were efficiency, $10(\% 3,6)$ were problem, $18(\% 6,5)$ were labor and saving, $3(\% 1,1)$ were other (Table 3$)$.

Table 3: Airport Security Personnel's Perspective on the Work Related Innovations Distribution Table

\begin{tabular}{lrrrr}
\hline & Frequency & Percentile & Current Percentile & Total Percentile \\
\hline Innovation & 101 & 36,6 & 36,6 & 36,6 \\
Convenience and comfort & 102 & 37,0 & 37,0 & 73,6 \\
Efficiency & 42 & 15,2 & 15,2 & 88,8 \\
Problem & 10 & 3,6 & 3,6 & 92,4 \\
Labor and Saving & 18 & 6,5 & 6,5 & 98,9 \\
Other & 3 & 1,1 & 1,1 & 100,0 \\
Total & 276 & 100,0 & 100,0 & \\
\hline
\end{tabular}

\subsection{Analysis of the Relationship between Technological Changes and Age}

\subsubsection{Investigation of the Relationship between the Type of Psychological Impact Caused by Technological Change and Age}

Hypothesis 1: There is no relationship between the monotony and boredom caused by technological change and the age of security personnel (HO). There is a relationship between the monotony and boredom caused by technological change and the age of the security personnel (H1). To test this hypothesis, Chi-Square independence test of the questionnaire was applied.

104 airport security personnel between the ages of 25-40 according to the cross table according to age variable due to the monotony and boredom caused by technological change; 96 security personnel aged 41-50; 98 security personnel over 40 years of age disagreed that the technological change applied caused monotony and annoyance. 
Table 4: The chi-square table according to the age variable with the effect of technological change creating monotony and boredom

\begin{tabular}{lccc} 
Chi-Square Tests & Value & df & Asymp. Sig. (2-sided) \\
\hline Pearson Chi-Square & $7,944(a)$ & 3 &, 047 \\
Likelihood Ratio & 9,088 & 3 &, 028 \\
Linear-by-Linear Association &, 668 & 1 &, 414 \\
N of Valid Cases & 276 & & \\
\hline a 0 cells $(, 0 \%)$ have expected count less than 5. The minimum expected count is 5,02.
\end{tabular}

As a result of the Chi-Square test in the table data were calculated as: $\chi 2=7,944, s d=4, p=0,047$. Since $\chi 2(2)=7,944, p=$ $0,047<0,05$, HO hypothesis is not accepted and it is stated that there is relationship. Monotony and boredom caused by technological change and the age of security personnel.

\subsubsection{Investigation of the Relationship between the Form of Social Impact of Technological Change and Age}

Hypothesis 2: There is no relationship between job dissatisfaction and age of security personnel due to the monotony created by technological change in airport security $(\mathbf{H O})$. There is a relationship between job dissatisfaction and age of security personnel due to the monotony created by technological change in airport security (H1).

100 airport security personnel between 25-40 years old according to the cross-table of age variables and job dissatisfaction due to the monotony created by technological change in airport security; 88 airport security personnel over 40 years of age stated that they do not participate in the job dissatisfaction due to the monotony created by technological change in airport security.

Table 5: Job Dissatisfaction and Age Variables due to the Monotony Created by Technological Change in Airport Security Chi-Square Table

\begin{tabular}{lccr}
\hline Chi-Square Tests & Value & df & Asymp. Sig. (2-sided) \\
\hline Pearson Chi-Square & $3,967(a)$ & 4 &, 411 \\
Likelihood Ratio & 4,086 & 4 &, 395 \\
Linear-by-Linear Association &, 038 & 1 &, 846 \\
N of Valid Cases & 276 & & \\
\hline a 2 cells $(20,0 \%)$ have expected count less than 5. The minimum expected count is 2,74.
\end{tabular}

As a result of the Chi-Square test in the table data were calculated as: $\chi 2=3,967, s d=4, p=0,411$. Since $\times 2(2)=$ $3,967 p=0,411>0,05, \mathrm{H} 0$ hypothesis is accepted and it is stated that there is no relationship between job dissatisfaction due to monotony created by technological change in airport security and the ages of security personnel.

\subsubsection{Examination of the Relationship between the Physical Impact of Technological Change and Age}

Hypothesis 2: There is no relationship between health problems experienced as a result of technological change in airport security and the age of security personnel $(\mathbf{H O})$. There is a relationship between the health problems experienced as a result of technological change in airport security and the ages of security personnel (H1).

With the increase in health problems as a result of technological change in airport security, 62 airport security personnel between 25-40 years of age and 36 airport security personnel over 40 years of age did not agree with the increase in health problems following the technological change in airport security. 26 airport security personnel over the age of 40 agreed that health problems increased after technological change in airport security (Table 6). 
Table 6: Increase in Health Problems as a Result of Technological Change in Airport Security and Age Variants Chi-Square Table

\begin{tabular}{lrrr}
\hline Chi-Square Tests & Value & df & Asymp. Sig. (2-sided) \\
\hline Pearson Chi-Square & $5,705(a)$ & 4 &, 222 \\
Likelihood Ratio & 5,744 & 4 &, 219 \\
Linear-by-Linear Association & 1,161 & 1 &, 281 \\
N of Valid Cases & 276 & & \\
\hline
\end{tabular}

a 0 cells $(, 0 \%)$ have expected count less than 5 . The minimum expected count is 6,85 .

As a result of the Chi-Square test in the table was calculated as $2=5,705, s d=4, p=0.222$. Since $\chi 2(2)=5.705 p=$ $0.222>0.05, \mathrm{HO}$ hypothesis is accepted and there is no correlation between the increase in health problems as a result of technological change in airport security and the age of security personnel.

\subsubsection{Investigation of the relationship between the economic impact of technological change and ages}

Hypothesis 3: There is no relationship between the concern of dismissal after technological change at the airport and the age of security personnel (HO). There is no relationship between the age of security personnel and the concern of dismissal after technological change at the airport (H1).

96 airport security personnel between the ages of 25-40 according to the cross table according to age variable due to concern about dismissal caused by technological change; 76 airport security personnel over the age of 40 disagreed that the technological change made worries about dismissal.

Table 7: Chi-Square Table according to the Age Variable and the Worry of Dismissal caused by Technological Change

\begin{tabular}{lrrr}
\hline Chi-Square Tests & Value & df & Asymp. Sig. (2-sided) \\
\hline Pearson Chi-Square & $3,187(\mathrm{a})$ & 4 &, 527 \\
Likelihood Ratio & 3,198 & 4 &, 525 \\
Linear-by-Linear Association &, 116 & 1 &, 733 \\
N of Valid Cases & 276 & & \\
\hline
\end{tabular}

a 2 cells $(20,0 \%)$ have expected count less than 5 . The minimum expected count is 3,65 .

As a result of the Chi-Square test in Table 27 was calculated as, $\chi 2=3,187, s d=40, p=0.527$. Since $\times 2(2)=4.574 p=0.527>$ $0.05, \mathrm{HO}$ hypothesis is accepted and there is no relationship between the concerns of dismissal caused by technological change and the age of security personnel.

\section{CONCLUSION}

As in many other sectors, the civil aviation sector is one of the sectors where technology is used extensively in its fields of activity. The safe and secure conduct of aviation activities and the minimization of security gaps in airports necessitate the use of technology in airport security. It is important to identify the technology used in airports, developments and changes in this area, the perspectives of airport security personnel who are users of technology, and to what extent and how they are affected by the change. Because the security of airports, taking necessary measures for this depends on the decisions of airport security personnel who are users of technology.

Technological changes can have effects on people such as monotony and boredom, fatigue, dismissal and stress. Technological change management should be performed according to these criteria as these effects vary according to the age, seniority in the profession and educational level. As a matter of fact, monotony and boredom; There is a correlation between the stressful environment effect resulting from technological change and the age of airport security personnel. Monotonous and boredom as a result of technological change in the business environment, stress effect management should be made taking into consideration the age criteria. 
As a result of analysis of hypothesis monotony and boredom caused by technological change and the age of security personnel. Moreover there is no relationship between job dissatisfaction due to monotony created by technological change in airport security and the ages of security personnel. And also, there is no correlation between the increase in health problems as a result of technological change in airport security and the age of security personnel. Another result of correlation analysis is that, there is no correlation between the increase in health problems as a result of technological change in airport security and the age of security personnel. And finally there is no relationship between the concerns of dismissal caused by technological change and the age of security personnel.

As a result of all this information, it can be said that the management of technological change is important for organizations. Ensuring security at airports is important in terms of minimizing the psychological, social, economic and physical impacts of technology on security personnel due to the key human factor.

Training of security personnel before the technological change to be applied increases the interaction between technology and individual and contributes to the personnel to make appropriate decisions because it recognizes the technology.

In addition, the adaptation of the person to the technology should be ensured by keeping the inadequacy arising from the lack of information in the face of technology resulting from technological changes in airport security to a minimum.

*This research result presented in Global Business Research Congress (GBRC-2019), 30-31 May 2019.

This research supported by SIHAGUVDER

\section{REFERENCES}

Adibifar, K. (2016). Technology and Alienation in Modern-Day Societies. International Journal of Social Science, 61-68. doi:https://doi.org/10.11114/ijsss.v4i9.1797

Alards-Tomalin, D., L.Ansons, T., C.Reich, T., Sakamoto, Y., Davie, R., e-McGowan, J. P., \& C.Leboe-McGowana, L. (2014). Airport security measures and their influence on enplanement intentions: Responses from leisure travelers attending a Canadian University. Journal of Air Transport Management, 37, 60-68. doi:https://doi.org/10.1016/j.jairtraman.2014.02.004

Ashford, N., Stanton, M. H., \& Moore, C. A. (1996). Airport Operations. Newyork: Airlife Publishing LTD.

Aydın, E. (2013). Teknolojik Değişikliklerin Çalışma Hayatına Etkileri ve Hastane Çalışanları Üzerinde Bir Araştırma. İstanbul: İstanbul Üniversitesi Yüksek Lisans Tezi.

Can, İ. (2008). Havacılık Güvenliği Açısından insan Kaynakları Yönetimi ve THY Teknik A.Ş.'nde Bir Araştırma. İstanbul: İstanbul: İstanbul Üniversitesi (Yüksek Lisans).

Cascio, W. F., \& Montealegre, R. (2016). How Technology Is Changing Work and Organizations. Annual Review of Organizational Psychology and Organizational Behavior, 3, 349-375. doi:https://doi.org/10.1146/annurev-orgpsych-041015-062352

Çakır, Ö. (. (2007). İ̧̧ini Kaybetme Kaygısı: İş Güvencesizliği. Çalışma ve Toplum, 1, 117-140.

Dertli, D. (2008). Örgütsel Bir Değişim Olarak Teknolojik Değişime Iş̧örrenlerin Yaklaşımı ve Işgörenlerde Etkisi: Öztay Tekstil (Abbate) Örneği. Kütahya: Dumlupınar Üniversitesi Yayımlanmamış Yüksek Lisans Tezi.

Elias, B. (2009). Airport and Aviation Security, U.S Policy and Strategy in Age of Global Terrorism. NewYork: Auerbachs Publications.

Erdoğan, T., Ünsar, A. S., \& Süt, N. (2009). Stresin Çalışanlar Üzerine Etkileri : Bir Araştırma. Süleyman Demirel Üniversitesi iktisadi ve Idari Bilimler Dergisi, 14(2), 447-461. 
Gökgöz, H. (2013). Stresin Çalışanların Performansı Üzerine Etkisi: Öğretim Elemanları Üzerine Bir Araştırma. Edirne: Trakya Üniversitesi Sosyal Bilimler Enstitüsü Yüksek Lisans Tezi.

Gürsoy, F. (2014). Sağlık Işletmeleri Personelinin Iş̧e Yabancılaşma Düzeyi: Van ilii Örneği . Ankara: Ankara: Atılım Üniversitesi (Yüksek Lisans Tezi). .

Hofer, F., \& Wetter, O. E. (2012). Operational and Human Factors Issues of New Airport ecurity TechnologyTwo Case studies, 5, . Journal of Transportation Security, 277-291.

Jain, A. K., \& Kumar, A. M. (2011). Biometric Recognition: An Overview. New York: Springer. doi:10.1007/978-94-007-3892-8_3

Kardeş, Y., Yılmaz, H., Ateş, S. S., Sayın, A. K., \& Gemici, E. (2014). Türkiye'de Havalimanlarında Görev Yapan Güvenlik Personelleri Üzerinde "Mesleğe Bağlılık Araştırması". INTAVIC, (pp. 4-18). Ankara.

Okutan, M., \& Tengilimoğlu, D. (2002). İş Ortamında Stres ve Stresle Başa Çıkma Yöntemleri: Bir Alan Uygulaması. G.Ü i.i.B.F Dergisi, 3, 15-42.

Oregon State University. (2018, March 18). Technology. Retrieved March 18, 2018, from Definitions of Technology: https://web.engr.oregonstate.edu/ funkk/Technology/technology.html

Örücü, E., \& Yumuşak, S. (2015). Örgütlerde İşgören Eğitimi Üzerine Bir Alan Araştırması. Iktisadi ve Idari Birimler Dergisi, 19(2), 235-246.

Özkan, Y., \& Purutçuoğlu, E. (2010). Yaşlılıkta Teknolojik Yeniliklerin Kabulünü Etkileyen Sosyalizasyon Süreci. Aile ve Toplum, 6(23), 37-46.

Sheen, D. M., McMakin, D. L., \& Hall, E. T. (2001). Three-Dimensional Millimeter- Wave Imaging for Concealed Weapon Detection. IEEE Transactions on Microwave Theory and Techniques, 9(49), 29-49.

Singh, S., \& \& Singh, M. (2013). Explosives detections systems (EDS) for aviation security. Signal Processing, 31-55.

Sweet, M. K. (2009). Aviation and Airport Security, Terrorism and Safety Concerns. Washington: CRC Press.

Şahin, L., Aydın, E., \& Güler, M. (2015). Teknolojik Gelişmelerin İşin Yapısı ve İşgücünün Nitelikleri Üzerine Etkileri: Hastane Çalışanlarının Algılarına Yönelik Bir Araştırma. Iş ve Hayat, 1(1), 97-130. 